\title{
THE SOUTH AFRICA WORLD CUP: THE ABILITY OF SMALL AND MEDIUM FIRMS TO PROFIT FROM INCREASED TOURISM SURROUNDING MEGA-EVENTS
}

\author{
BOB HEERE,* PIETER VAN DER MANDEN,† AND PATRICIA VAN HEMERT $\ddagger \S$ \\ *University of South Carolina, Columbia, SC, USA \\ †Rainbow Collection, Amsterdam, Netherlands \\ $\ddagger$ Vrije Universiteit Amsterdam, Amsterdam, Netherlands \\ §Maastricht University, Maastricht, Netherlands
}

\begin{abstract}
The purpose of this study is to implement a microeconomic lens to examine how a mega-sport event affects small and medium businesses (SMEs) that hope to profit from the increased tourism associated with the event. Guided by stakeholder theory, local SME owners were interviewed before and after the World Cup. Respondents suggested that the opportunities to take advantage of the World Cup were limited for SMEs because: a) limited or no access to the event and associated tourists, b) lack of knowledge and expertise to take advantage of opportunities, and c) the priority the organizing committee gives to other stakeholders, such as sponsors and the FIFA. Due to these constraints, SMEs were not able to build lasting partnerships through the World Cup, nor were they able to make any profit from the event.
\end{abstract}

Key words: Mega-sport event; World Cup; Small and medium businesses (SMEs)

Introduction

For the first time in history, the football World Cup was organized on African soil, and for a short period of time, the eyes of the world were on South Africa. Many politicians claim these mega-sport events have a major economic impact on their nation, and thus they are willing to spend considerable amounts of public money in order to support the bidding and hosting of these events (Burgan \&
Mules, 1992). However, academic scholars have been highly critical of the economic impact of these events and argue that these mega-events add little to nothing for the local economy (Crompton, 1995; Hall, 1992, 2004; Hall \& Page, 2008). While the event might have a short-term effect on tourism, there is little empirical evidence that these megaevents will have a long-lasting effect (Matheson, 2006a, 2006b). Rose and Spiegel (2009) claimed a positive effect of bidding for these events on both 
export and overall trade, yet from their article it is unclear what the causality within this relationship is. Over the last 20 years many nations that bid for mega-events already had growing economies before the bidding process started (Brazil, Russia, South Africa, China, South Korea). After calculating the long-term economic impacts of the Summer Olympics for host cities between 1950 and 2005, Billings and Holladay (2012) argued: "that host cities bid away potential benefits in an effort to win the right to host the [mega-event]" (p. 771). Shaw (2008) went as far as to claim that all these megaevents do is move tax money from the public to a small and exclusive group of project managers and event organizers.

In particular, it is unclear how these events affect tourism and what sectors of the tourism industry in the host nation are able to profit from the event. Coates and Humphreys (2002) and Preuss (2003) suggested that many of these events cause a "crowding-out" effect, indicating that these events did not necessarily increase the overall number of tourists, because the event tourists cause other tourists to stay away from the host city. Despite this criticism, the economic impact of tourism on a destination is widely accepted as an economic engine for many economies (Archer \& Fletcher, 1996), and the organization of international sport events might be a justifiable investment to further increase tourism for a destination, if this event allows the local economy to take advantage of these new incoming groups of tourists. Therefore, there is a need to better understand how local businesses are able to take advantage of this event.

Over the last decade, international sport federations have attempted to further increase the popularity of their sports around the globe by letting these developing nations organize their hallmark events. This makes the discussion of how such a mega-sport event affects a local economy particularly salient, as the economic impact of tourism within a developing nation might be more complicated to grasp. Due to historic political and economic structures, the revenues from tourism do not always benefit the people as they should (Brohman, 1996), making it more complicated to measure the impact of a potential increase. Often, the increased revenues remain with the multinational companies (e.g., hotels, resorts) and the local economy hardly benefits from the increased tourism. Thus, we know very little how these mega-sport events impact the local economy beyond the reach of the multinational companies.

Additionally, rather than examining these events based on their potential outcomes, a call has been put forward to examine the processes behind these outcomes, and evaluate how we can leverage these processes in order to maximize output (Chalip, 2004). In the context of mega-events, some researchers have defined leveraging as the process through which the benefits of investment are maximized (Bolton, Kannan, \& Bramlett, 2000; Slywotsky \& Shapiro, 1993). According to Chalip, more emphasis should be placed on leveraging processes in order to increase spending, the image of a host nation, and increased tourism (Chalip, 2001, 2004; Chalip \& Leyns, 2002). An empirical investigation of local businesses on the Australian Gold coast revealed that many local businesses had little idea of how to use a large sport event for the benefit of their own business (Chalip \& Leyns, 2002). While economic scholars have illustrated the lack of economic impact of these mega-events quite well (Billings \& Holladay, 2012), there is still a gap in the literature on the reasons for this lack of impact. Why are local businesses unable to take advantage of these events?

Thus, in order to gain more insight on the contradictory views on the economic impact of mega-sport events, we aimed to examine the effect of a megasport event on one particular stakeholder group: the SMEs in South Africa. To that end, we systematically interviewed 14 local entrepreneurs months before and after the World Cup through phone and Skype to ask them about their perception of the economic effect of the World Cup on their business. We asked about what they expected to get out of the event, and whether they believed the event to have had a positive effect on their business.

\section{Literature Review}

\section{The Economic Value of Small and Medium Enterprises}

In developed nations, entities with fewer than 500 employees are usually considered SMEs (U.S. Small Business Administration, 2012), while in developing countries the thresholds are generally lower. For 
instance, in South Africa, businesses ranging from 1 to 200 employees are considered to be SMEs. Medium businesses have less than 200 employees; small businesses have less than 50 employees, very small businesses less than 20 employees, and microbusinesses less than 5 employees (Department of Trade \& Industry South Africa, 2004).

In 1911, Schumpeter argued in his theory of economic growth that SMEs are the power of economic development (Schumpeter, 1934). SMEs contribute significantly to economic growth, employment, and social development (Enright, Ffowcs-Williams, \& Nolan, 2001) and are therefore an important driving force of economic development. This was confirmed by Acs (1992), who distinguishes four consequences of the importance of SMEs and claims that SMEs play an important role in the regional development and economy: (1) they are a vehicle for entrepreneurship, (2) they create routes of innovation, (3) they encourage industry dynamics, and (4) they create a substantial part of the domestic workforce. Thus, SMEs play a significant role in several indicators of regional development. These indicators for a developed region include employment and the existence of a dynamic entrepreneurial climate where SMEs and larger enterprises (LEs) collaborate (Acs, 1992). It is interesting to see that these indicators tend to be similar to the proclaimed legacies of mega-events (Cashman, 2005; Chalip, 2001; Haxton, 2000; Kasimati, 2003; Kesenne, 2005; Lenskyj, 2000, 2002; Moragas, Kennett, \& Puig, 2003; Preuss, 2004; Ritchie \& Aitken, 1984; Rose \& Spiegel, 2009; Vigor, Mean, \& Tims, 2004).

Additionally, SMEs play a role in the attraction of LEs, or multinational corporations (MNCs) and they benefit from the presence of LEs. The relation between SMEs and LEs can be best captured as SMEs being the subcontractors or suppliers of LEs. Globalization is an important factor in the attraction of LEs. The globalization of production has today reached an unprecedented extent, with the production of goods and services increasingly fragmented across several firms. LEs generally lead this process, creating diverse opportunities and challenges for their traditional partners, suppliers, and distributors (Organisation for Economic Co-operation and Development [OECD], 2007). Firms that have successfully integrated one or more value chains have been able to expand their business, and gain stability. SMEs that focus on multipurpose technologies have secured their position in the market by becoming a specialized supplier and serve different global value chains (OECD, 2007). Thus, SMEs and LEs together form a global value chain (GVC). The establishment of LEs in developing countries is therefore highly dependent on the quality and diversity of SMEs (Kimura, 2006). At such a sophisticated stage of development of the formation of production networks, SMEs play a crucial role. Lim and Kimura (2009) suggest that SMEs are essential components of production networks and essential components of industrial agglomeration. So, SMEs can be important participants in a divisions labor supply. In Singapore, for example, SMEs provide a flexible amount of educated labor that attracts multinationals or LEs (Kimura, 2006).

However, the relationship between SMEs and LEs in developing nations is not always a positive one, and the tourism industry does not form an exception to this rule (Brohman, 1996). Harrison (1994) noted that in developing nations, LEs could have a negative effect on local SMEs and prevent further growth. Kirsten and Rogerson (2002) examined the relationship between LEs and SMEs in the South African tourism industry and came to the conclusion that the relationship between both is characterized by many challenges. Due to the lack of education, finances, and product quality provided by SME owners, LEs are hesitant to make use of SMEs and often refrain from doing so.

Because of the enormous value of SMEs to domestic employment and as suppliers for LEs across the globe, the question of how these companies are used by event organizations in order to leverage certain economic outcomes is crucial to the economic success of the host nation. An analysis of the SME industry in Ghana and Tanzania showed that the companies account for $92 \%$ of the workforce in Ghana and $60 \%$ of the workforce in Tanzania, and they contributed between 40\% (Tanzania) and $70 \%$ of the gross domestic product. According to these authors, the SMEs in Ghana were largely responsible for the poverty rate to decrease from $51.7 \%$ in $1991-1992$ to $28.5 \%$ in $2005-2006$ (Ubabuko, Ally Kavuwo, Kwaasi Adjei, \& Shahihuzzaman, 2010). The reliance on these SMEs is delicate, as the turnover for these companies is high. According to a study in South Africa, almost 30\% 
of businesses die (or become dormant) less than 3 years after registering. The proportion of businesses surviving for more than 10 years is just over one quarter (The Department of Trade \& Industry South Africa, 2004). Understanding the conditions for these companies to survive is at the forefront of economic policy for these nations. Most of these SMEs are within the trading industry, and $79 \%$ of them sell products (FinScope South Africa Small Business Survey, 2010). According to Goodwin (2000), improving the access of local SMEs to tourism markets, thus benefiting their chances of survival, is an essential element of alleviating poverty. In order to better understand how these companies are affected by a mega-sport event, stakeholder theory offers a valuable framework.

\section{Stakeholder Theory}

Stakeholder theory provides a framework to analyze an organization and any person and/or group that is affected by the decisions of the organization and, in return, might influence the decisions of the organization (Freeman, 1984). In light of a particular issue, these stakeholders can be classified according to: 1) power, which reflects the capacity of the stakeholder to influence the outcome of the issue, 2) legitimacy of the relationship of the stakeholder with the organization, and 3) the urgency of the stakeholder's claim on the organization (Mitchell, Agle, \& Wood, 1997). According to Parent (2008), organizing committees spend large amount of time and money building relationships with the various stakeholder groups so they can acquire the necessary resources to host the event. Throughout the different stages of bidding and planning for the event, the different issues that become priorities to the organizing committee change (Parent, 2008), reflecting a dynamic relationship between the organizing committee and each of the stakeholders based on power, legitimacy, and urgency.

In the bidding phase, local stakeholders such as the SMEs and special interest groups still have considerable power because of their capacity to influence public support, and are thus perceived as important and legitimate (Lenskyj, 2000). Because of this power, organizing committees spend considerable resources to ensure the support from these groups. During this stage, the event is proclaimed to be a sound investment that brings enormous returns on the initial investment that has to be made to make the event a reality (Cottle, 2010). In the initial 2010 World Cup bid, the South African government claimed that no new stadiums would be built and that the event could be held through renovation of its current stadiums, which would require a budget of approximately \$260 million (Cottle, 2010). In exchange for this investment, many believed the World Cup would cause increased patriotism and would enhance the worldwide reputation of South Africa (Walker et al., 2013). Additionally, the event was believed to give the national economy a boost through increased tourism.

The tourism industry forms one of those local interests groups that receives a lot of attention from the bid committee in the bidding process (Cottle, 2010), yet due to the fragmented nature of the industry, this does not necessarily mean their lobby is effective (Bregoli \& Del Chiappa, 2013). Once the bid is won, and the government has committed to the organization of the event it becomes much harder for local groups to influence public opinion, thus the organizing committee turns its priorities to the international sport federation (e.g., FIFA) and their sponsors, whose needs are perceived as more urgent (Cottle, 2010; Shaw, 2008). Over the last few decades, the international sport federations and their stakeholders (e.g., sponsors, media) have increasingly become more important, demanding preferential treatment over local stakeholders, often formulated in a set of "guarantees" (Jennings, 2010). While prominent hotels often remain on the radar of the organizing committee because of their importance to the international stakeholders, other sectors of the tourism industry receive less attention, as they have little leverage to negotiate at this stage. During this stage, the emphasis of the event as an instrument to produce positive outcomes for the host society became secondary to the focus on putting together the best possible event, regardless of the expenses.

In their desire to put together the best possible event, the South African government promised to increase their budget to renovate existing stadiums, and more importantly, created a budget to build new stadiums. After the bid was awarded the $\$ 260$ million budget for stadiums was increased to as much as $\$ 4.5$ billion (Cottle, 2010). These increased expenses were deemed critical by the South African 
organizing committee to keep the support of their international stakeholders and to prevent negative publicity for the nation, yet meant there was little money left for other endeavors.

The relationship between the South African organizing committee and the FIFA did not only affect the costs of the event, it also affected the relationship between the organizing committee and local stakeholders. In the short documentary Trade mark 2010 (Boon \& Bertacchini, 2009), the plans of the FIFA and the South African organizing committee were scrutinized as they offered little incentives to microenterprises and entrepreneurs, despite the presence of a huge small, micro, and medium enterprise (SME) sector in South Africa. In 2010, the overall SME sector was estimated to consist of roughly 6 million businesses, which means that one out of every six individuals above the age of 16 has their own business venture (FinScope South Africa Small Business Survey, 2010). What was revealed in this documentary was that local entrepreneurs were not given the opportunity to develop any economic activity as the contracts of the FIFA laid claim to all trademarks associated with the World Cup (inclusive of city names, and the year 2010), and the space surrounding the stadiums. In some cases that even meant that local SMEs were displaced from their current highly visible locations and were not able to continue their business as usual, just to ensure exclusivity for the relations of the FIFA and/ or the organizing committee. For instance, a restaurant that had been selling hamburgers for years in one of the areas would no longer be allowed to sell them because those places were claimed for McDonald's. In order to appease their international stakeholders the organizing committee was forced to look at the sport event as the final goal (e.g., put together the best event possible), rather than as a means to a goal (e.g., the World Cup benefits the nation economically and socially), and by adapting this position, concessions were made at the expense of the local stakeholders.

While we have a strong understanding of the potential macroeconomic effects of mega-sport events, we know very little of the microeconomic processes that might occur between stakeholder groups because of the event. This is surprising, because it is these processes that are at the root of any macroeconomic effect and play a crucial role in any attempt to leverage the event for economic gain. There seems a discrepancy between FIFA's claim that their events have a positive effect on the local economy and their desire to offer their top sponsors and suppliers exclusivity in and around the stadiums at the expense of the local entrepreneurs. Rather than profiting from the event directly, the SMEs actually are prohibited to do so to protect the exclusivity of the top sponsors, thereby potentially hurting the local economy, instead of stimulating it.

\section{The Changing Relationship Between Organizing Committees and Their International Stakeholders}

After the economic debacle of the Montreal Olympics in 1976 and the boycotts of the Moscow Olympics in 1980, there were few nations still willing to host a mega-sport event and the International Olympic Committee (IOC) had no choice other than to award the Summer Olympics to Los Angeles, the sole bidder for the Games (Jones, 2001). Because Los Angeles was the only bidder, they were able to exert more power in their relationship with the IOC and prioritize the needs of the local stakeholders (keep costs low, gain higher involvement of local sponsors and US broadcasting partners) over those of the IOC. Consequently, the Los Angeles organizing committee made use of as many existing facilities as they could, including the Los Angeles Memorial Coliseum, which had served as the Olympic Stadium of the 1932 Games. Because of the low cost of the organization, and the innovative approach of the American organizers towards broadcasting the event on television, the event was an economic success, providing a foundation to the claim that these mega-events can be profitable for the host nation (Preuss, 2004).

During subsequent Summer Olympics in emerging markets such as Spain (which had just entered the European Union) and South Korea, the IOC quickly caught on to the commercial approach of the American organizers, and due to increased competition between bidding cities, were able to exert more power over the local organizing committees. Cities that followed Los Angeles in their footsteps had to make promises to build bigger and better facilities in order to win the bid, and give the IOC and their stakeholders more access to the event, thereby increasing the cost for organizing the 
event. This transformation was not unique to the IOC and the Olympics, as the FIFA and the organization followed a similar path (Cottle, 2010).

Aside from the increasing costs, the revenue model for the host city or nation has changed as well, since International Sport Federations (ISFs) have increasingly asked for more tax exemptions and are currently demanding a complete exemption for themselves and any of the partners involved with the event (Jennings, 2010). Additionally, over the last two decades both the IOC and the ISFs have been able to generate considerable sponsorship revenues, mainly because of their promise to offer exclusivity surrounding the event. Between 2005 and 2008, the IOC made \$866 million from their sponsors, while the local organizing committee earned another $\$ 1.5$ billion from national sponsors (International Olympic Committee, 2010). Each of these sponsors is offered some level of exclusivity, especially in and around the stadiums. How these changing conditions surrounding mega-sport event hosting have affected the opportunities of local SMEs to leverage the event for their own benefit remains unclear. Examining the opportunities for SMEs surrounding the World Cup could shed further light on the findings of economists of why these mega-sport events do not provide positive economic effects for their host societies (Matheson, 2006a, 2006b).

\section{Method}

\section{Sample}

Through the support of two South African governmental bodies, The Cape Craft Design Institute (CCDI) and the Department of Trade \& Industry (DTI), 50 SMEs in the Western Cape Province were contacted for interviews. The SMEs were randomly chosen by the CCDI from their overall database containing 8,000 companies in the craft and design industry and all of them produced and/or sold goods. During the World Cup, nine games would be played in Cape Town, six first round games, one second round game, a quarterfinal and a semifinal game. Only Johannesburg would host more games. During the months of June and July, 1.4 million tourists would visit the nation, of which slightly more than 300,000 indicated that the World Cup was the purpose for their trip. Of those 300,000, approximately
108,000 would visit Cape Town (South African Tourism, 2010). We chose to focus on this sector as shopping was one of the most mentioned activities the tourists undertook, and many tourists were likely looking for some memorabilia that reminded them of their trip (South African Tourism, 2010). A study conducted by the Western Cape Province (Cape Craft \& Design Institute, 2004) suggested the SMEs within the craft industry would be among those most likely to profit from the event, because tourists would buy their products. Thus, if the increased tourism would have any effect on the local economy, this would be a sector that would profit from it. Second, we chose to interview business owners from this industry, because the industry is characterized by low barriers for entry, and requires little education from employees, making them especially valuable as SMEs that can alleviate poverty. Finally, the craft and design sector is interesting because they have to deal with the blockades introduced by the FIFA. The Western Cape craft sector consists of around 8,000 enterprises. From this database the CCDI sent out invitations to 50 SMEs from the craft and deigns sector. While 50 SMEs are a relative small number that cannot be regarded as representative for the overall craft and design sector, for the purposes of qualitative interviews, we believed that this number would provide sufficient numbers to comprehend the major issues and challenges that these SME owners face.

Of the 50 SME owners approached, 14 agreed to an interview via phone or Skype. While this number might indicate some response bias, as companies that are well organized are more likely to respond, the turnover for SME companies is so high that the database probably did contain some businesses that were no longer active and check their emails. According to Sandelowski (1995), data analysis within a qualitative study requires at least 10 cases, and for this study we did notice that the responses became saturated towards the end, with owners simply reiterating what other owners already had discussed. After coding the interviews, one interview had to be discarded because of the low quality of the audio, resulting in 13 interviews. When these 13 owners were approached again after the World Cup, 12 of them responded. Additionally, interviews were held with each of the two governmental bodies that supported this study. Both entities aim to foster 
business opportunities and assist the SMEs with organizational issues that might arise.

The CCDI is a service provider to the city of Cape Town as part of the city's initiative to prepare the SME sector for the World Cup 2010. The task of the CCDI was to assist the craft sector (which includes companies producing beaded and ceramic products, jewelries, and other craft products) to sell more products during the World Cup, and to support them to improve their flexibility and creativity by demonstrating the value of creating tailor-made products for certain events or places. These governmental bodies presented the "other side of the story" and provided a level of triangulation towards the responses of the business owners. The vast majority of the companies were located in the city of Cape Town and only three companies were spread around the city, up to $30 \mathrm{~km}$ away from the city center. These 13 companies are not meant to represent the overall body of SME in South Africa, and the fact that they were from the craft and art sector might mean that the findings do not necessarily generalize to other small businesses, such as in the food and hospitality industry.

\section{Interviews}

A month prior to the event, semistructured interviews were conducted with the owners through Skype and over the phone. These interviews lasted approximately 30 minutes to an hour. Because of the use of a medium through which the interviews occurred, the interviewer spent considerable time with introductory questions that were aimed to make the interviewee more comfortable, before more critical questions were posed regarding the event itself. Most of these questions were aimed to gain insight on their expectations of the event and how it would affect their business. The two governmental organizations were asked a different set of questions, aimed to gain a better insight of the opportunities offered to the SMEs. About a year after the World Cup, the SME owners were contacted again and asked if they were willing to answer some questions about the World Cup through email once more. Because these questions were more structured and relatively straightforward (e.g., "Looking back, what did you get out of the World Cup? Do you believe the event to have been a success?” etc.), we wanted to give the respondents a bit more time to reflect and return them in written form, rather than through live interviews. By changing the format from an oral interview to a written questionnaire, we hoped to improve the recall of the respondents of the event, and improve the triangulation of the study.

\section{Data Analysis}

Guided by the literature on such subject and by stakeholder theory, data analysis was completed through a process proposed by O’Leary (2005). According to O'Leary, the process of analyzing qualitative data should entail four phases. First, the researchers read and reread the data at different points in time to gain a basic understanding of the data. Second, the researchers build upon their understanding of the data through the use of notes, memos, or other documentation. Third, the researchers organized and coded the data based on broad themes. These themes became the headings for the different result sections. Fourth, the researchers searched for patterns to develop and/or build new theories. To triangulate the data, the researchers used investigator triangulation, where the same researcher (insider) conducted the interviews while the other researcher remained on the outside. Then, throughout the four stages the researchers went back and forth and (dis) agreed on the emerging themes from the data (Miles \& Huberman, 1994). The researchers did not use a numerical coding system; instead they ordered data under headings and themes common to this type of study and often originated directly from the questions. The research design of conducting preevent and postevent interviews also served to triangulate the data, as many of the postinterviews disconfirmed some of the expectations and statements of the SME owners. While this study was exploratory, there was quite a bit of literature about the main issues in this article, allowing the researchers a more precise interpretation of the data.

\section{Results}

\section{The Expectations and Strategies of the SME Owners}

The group of owners had a diverse background with business ranging from products made of 
recycled materials, to light installations and chandeliers. Nine of the owners were male and four of them were female. Seven of them sold the majority of their products to companies in foreign nations, which indicated that they were part of some global value chain (GVC). Some of the SMEs had no employees, while others had anywhere from 1 to 20 full-time employees (FTE). In many instances, owners explained that this number varied from month to month.

When the SME owners were asked about their expectations of the World Cup and what it would bring to them, they provided mixed responses (see Table 1). Some owners, such as John (small gifts/jewelry), were positive because they expected increased tourism:

Table 1

The SMEs and the World Cup

\begin{tabular}{|c|c|c|c|c|}
\hline Owner (Business) & Size $^{a}$ & $\begin{array}{c}\% \text { of Revenue Based } \\
\text { on Export }\end{array}$ & $\begin{array}{l}\text { Planned Leverage } \\
\text { Strategies }\end{array}$ & $\begin{array}{l}\text { Effect of World Cup on } \\
\text { Own Business }\end{array}$ \\
\hline Graham (Ceramic products) & $11.5 \mathrm{FTE}$ & $\begin{array}{l}50 \% \text { exports to } \\
\text { Germany and } \\
\text { Australia }\end{array}$ & $\begin{array}{l}\text { Extra advertising, extra } \\
\text { inventory, a stand } \\
\text { at fanfests }\end{array}$ & $\begin{array}{l}\text { Very little-did not sell } \\
\text { inventory, many items } \\
\text { left over }\end{array}$ \\
\hline John (Small gifts, jewelry) & N/A & $\begin{array}{l}10 \% \text { exports } \\
\text { to France } \\
\text { and Australia }\end{array}$ & $\begin{array}{l}\text { Creating larger inventory, } \\
\text { hiring more people, a } \\
\text { stand at fanfests }\end{array}$ & $\begin{array}{l}\text { Some extra sales, but not } \\
\text { more profit because of } \\
\text { increased costs }\end{array}$ \\
\hline Ellen (Wool products) & $8 \mathrm{FTE}$ & N/A & A stand at fanfest & None \\
\hline $\begin{array}{l}\text { Nelson (Beadwork and } \\
\text { wire products) }\end{array}$ & 4-15 FTE & $\begin{array}{l}\text { N/A, exports to } \\
\text { Angola, Europe, } \\
\text { Suisse, UK, US }\end{array}$ & $\begin{array}{l}\text { None-sell to } \\
\text { hotels overseas. }\end{array}$ & $\begin{array}{l}\text { Did not agree to post } \\
\text { event interview }\end{array}$ \\
\hline $\begin{array}{l}\text { Matthew (Leatherwork: } \\
\text { handbags, keyrings, etc.) }\end{array}$ & $9 \mathrm{FTE}$ & $\begin{array}{l}80 \% \text {, exports } \\
\text { to Germany, } \\
\text { Belgium, Namibia, } \\
\text { Canada, Japan }\end{array}$ & $\begin{array}{l}\text { None-feels products } \\
\text { are too high end. }\end{array}$ & None \\
\hline $\begin{array}{l}\text { Jeff (Recycled township } \\
\text { craft products) }\end{array}$ & $5 \mathrm{FTE}$ & $\begin{array}{l}\text { 80\% export } \\
\text { to Europe, } \\
\text { Canada, USA, } \\
\text { Australia, Israel }\end{array}$ & $\begin{array}{l}\text { None-does not believe } \\
\text { World Cup will help } \\
\text { his business; even cut } \\
\text { back on expenses }\end{array}$ & $\begin{array}{l}\text { Negative effect of World } \\
\text { Cup on business; } \\
\text { uncertainty around the } \\
\text { event led to smaller } \\
\text { orders }\end{array}$ \\
\hline Margaret (Ceramic products) & $5 \mathrm{FTE}$ & $60 \%$ & $\begin{array}{l}\text { None, only sees } \\
\text { indirect opportunities } \\
\text { from event }\end{array}$ & $\begin{array}{l}\text { None, except for } \\
\text { one larger order } \\
\text { from Germany }\end{array}$ \\
\hline Mandisa (Interior decorating) & $1-10 \mathrm{FTE}$ & $\begin{array}{l}\text { Small percentage } \\
\text { to Germany }\end{array}$ & $\begin{array}{l}\text { Attending exhibition; } \\
\text { producing vuvuzela's }\end{array}$ & $\begin{array}{l}\text { Negative effect, sales } \\
\text { did not work out }\end{array}$ \\
\hline $\begin{array}{l}\text { Tom (Beadwork, paper marche, } \\
\text { recycled products) }\end{array}$ & N/A & $75 \%$ export & None & $\begin{array}{l}\text { Received more orders } \\
\text { prior to event, leading } \\
\text { to extra sales. }\end{array}$ \\
\hline Saskia (Design and accessories) & N/A & $\begin{array}{l}\text { Majority of sales to } \\
\text { Germany, Finland, } \\
\text { Sweden, Spain, } \\
\text { France, US }\end{array}$ & $\begin{array}{l}\text { Exhibiting in } \\
\text { trade show }\end{array}$ & $\begin{array}{l}\text { None, sales went down } \\
\text { and she is selling } \\
\text { her business }\end{array}$ \\
\hline Fred (Bead and wire art) & 20 FTE & $\begin{array}{l}\text { Less than } 10 \% \\
\text { to US }\end{array}$ & $\begin{array}{l}\text { Produced beaded } \\
\text { vuvuzela's }\end{array}$ & $\begin{array}{l}\text { Positive-turnover } \\
\text { increased strongly prior } \\
\text { to World Cup; dried up } \\
\text { after World Cup }\end{array}$ \\
\hline $\begin{array}{l}\text { Bob (Recycling, light } \\
\text { installations, chandeliers) }\end{array}$ & 5 FTE & $\begin{array}{l}\text { 60\% export to } \\
\text { UK, US }\end{array}$ & $\begin{array}{l}\text { None-not his } \\
\text { target market. }\end{array}$ & None \\
\hline Peter (Jewelry, corporate gifts) & N/A & Very small scale & $\begin{array}{l}\text { Attended fanfest, after } \\
\text { another trade show } \\
\text { was cancelled }\end{array}$ & $\begin{array}{l}\text { None-fanfest was } \\
\text { too "cramped" }\end{array}$ \\
\hline
\end{tabular}

${ }^{a}$ Size was measured in full-time employment (FTE). 
Yes, there are opportunities. The world is big, and they will notice us, so we hope that everybody sees our products and place corporate gift orders, which is a very big market. We make high end products and I expect that the people who are coming are really my type of customer.

Other owners were more hesitant: "I do not know how much more business we will get. Maybe through tourism. It is hard to predict” (Fred, Bead and wire art), and those owners discussed the World Cup more as a gamble: "I have decided to put money on it and if it fails, so be it" (Graham, Ceramics). Those owners who did not believe that the World Cup would have a positive effect on their business often felt that either their product did not fit with tourists who came to South Africa, or that the event would not result in sustainable revenue increases. One owner stated: "Maybe some [additional] World Cup sales during and after the World Cup, but I do not see it sustain and be of significant value” (Tom, Beadwork).

\section{Restrictions for SMEs}

One of the themes we identified after analyzing the interviews is that many owners were aware of the restrictions they were faced with. Those restrictions centered around two main subjects: 1) Merchandise could not be sold around the stadiums, except for designated fan zones. For those fan zones, one would need a permit. 2) Merchants were not allowed to use any specific terms, words, or phrases associated with the World Cup and would infringe their trademark. These restrictions formed the main reason that many owners did not have high expectations of the event, even if they did express the desire to participate in World Cup-related activities. As Graham (Ceramics) put it: "People are afraid of the restrictions." He lost some of the enthusiasm he had because he was not allowed to use stripes on his ceramic bowls and had to refrain from making any reference to the event. Similarly, Ellen (Wool products) felt that the restrictions took away most of the opportunities, claiming that the special areas in the fan zones coordinated by the CCDI were the only way to get access. Unfortunately, that access was limited and came at a price. When the employee of the CCDI was asked about what the organization was doing for the World Cup, the main activity she brought forward was: "Workshops have been held by the CCDI Rural Outreach Officer and facilitators in spelling out the FIFA guidelines and encouraging innovation and creativity." While this was not the only activity that the CCDI organized, it emphasized the focus of the authorities on the protection of the World Cup brand as a first priority. Entrepreneurs were firstly informed about the rules of what was allowed and what the restrictions for the local SME owners were.

Peter (Jewelry) perceived the event to have a negative effect because of the restrictions, stating that: "Lots of constraints. Just some opportunities in a fan park for 800 CCDI members for eight matches in Cape Town. This is not enough.” Jeff (Recycled products) blamed the FIFA, claiming that: "There is potential in the World Cup if some people would not have been that greedy, like the FIFA." Because of these restrictions many owners did not develop activities that were directly related to the event (see Table 1), and if they did, they were mainly confined to attending the exhibitions, or creating extra inventory. A few owners were considering advertising, yet they did not express any advertising ideas.

\section{The Perceived Impact of the World Cup}

When the owners were approached after the event to ask about the overall impact of the World Cup on their nation, most owners maintained a positive view of the event in general. As Peter (Jewelry) stated: "It was very good for the country as a whole bringing people together from all walks of life, there was a great sense of safety and camaraderie. . . . I believe it has raised the profile of South Africa." According to Mandisa (Interior decorating): "it had a huge impact on the business side and already established businesses; it also highlighted the country in terms of tourism and what it can offer.” Only three owners were more critical towards the event in hindsight. Tom (Beadwork) questioned its ability to raise South Africa's profile and thought that all the event did was: "adding some expensive infrastructure, mainly stadia.” Jeff (Recycled products) wondered if it was worth the investment:

One would need to make an honest calculation of the cost of the event, versus the value of the inflow gained from it. . . Many will argue that 
the positives can't be measured in Rands (South African currency) and cents, but then what is the point? Is it in the end not meant to make money?

Even though many owners thought the event had a positive impact on the nation in general, few of them thought it had a positive effect on their own business (see Table 1). Only three owners claimed extra revenue, albeit they acknowledged this increase was either temporary and/or limited. Others actually thought the event had a negative effect on their business, because of the uncertainty around the event or the fact that it took business away from regular customers. In general, there was a belief the event did very little for small businesses. Jeff (Recycled products) believed it was because the event "attracted the wrong clientele.” John (Small gifts) shared that view: "In general, the crowd that visited were soccer supporters, not furniture buyers.”

Besides the lack of fit between the tourists who came to the nation for the events and the products the SMEs offered, the restrictions put on the craft and merchandise industry by the FIFA and the local organizing committee gave the impression that the SME owners could do little to make money off the event. While the CCDI had several programs that allowed owners to become part of the fan fests, not everyone was aware of them: "Unfortunately [my business] did not have the opportunity to take part in the event and I do believe there were very strict rules as to who could sell what and where" (Saskia, Accessories). Even when they were involved with some of the opportunities that CCDI had set up, the restrictions placed upon the production that forbid any direct association with the World Cup event was seen as very discouraging: "I am just not encouraged by the branding legislation that prevented local enterprises from garnering an income by not being able to use key marketing words such as 'soccer' and 2010" (Bob, Recyled products). According to Peter (Jewelry), the programs that the CCDI promoted might even have had a negative effect, as it encouraged SMEs to spend "Lots of development and time on creating new 'soccerrelated' products, which in turn did not generate additional income. Personally, I do not know of any crafter that benefited greatly from FIFA." Since most of these products were related to soccer in general, but not to the World Cup itself, these products were perceived as inferior to the official merchandise offered in the fan zones. Bob believed it hurt the SMEs after the World Cup:

\begin{abstract}
The downside of the 2010 FIFA event is that tourists coming from elsewhere to South Africa merely shifted their visit to the time of the FIFA events. Later during the summer, the crash was felt as the tourist industry was lower in turnover for microenterprises in my neck of the woods.
\end{abstract}

Ultimately, the FIFA was seen as the culprit in this situation, as they were perceived to be responsible for all the restrictions. Fred (Bead and wire art) was perhaps the only owner who was capable of making significant revenue from the event and even he stated:

FIFA allowed small businesses to benefit from the event by selling and supplying to the market place various items which did not compete with their brand. Overall, I don't think they did enough to grow small businesses in South Africa. It seems that after the event they were more interested in growing their own profit.

Jeff (Recycled products) was more outspoken:

FIFA did absolutely nothing for small or micro businesses in South Africa. . . . FIFA sells advertising rights and the right to host and the right to televise the event. After that, all that FIFA does is prevent anyone else from using their trademarks. ... FIFA has a business model which is not interested in promoting anyone other than itself.

Tony (Ceramic products) shared this cynical view and summarized perhaps best how the SME owners experienced the event:

I truly believe that South Africa was manipulated by FIFA and that it should have bargained harder to get some social 'upliftment' from them in return. It definitely feels as though they got everything they wanted and now this country has to pick up the pieces behind them. FIFA is a business and did not take into account the poverty and the smaller entrepreneurs here.

\section{Discussion}

The respondents illustrate the potential conflicting positions of the international and local stakeholders. They had a hostile view of the international 
stakeholders, who they felt excluded them from the World Cup event, so they were able to preserve their exclusivity. The FIFA generated approximately $\$ 3.2$ billion from the 2010 World Cup, 95\% of this number directly related to the rights fees. Protecting these right fees is extremely important to the organization (Rambler, 2010).

Despite the support of organizations such as CCDI and DTI, the lack of access to the event and the barriers that SMEs were faced with prevented any economic spin-off that could have happened as a consequence of the increased tourism surrounding the event. When the SME owners did gain access to the tourists who were there because of the event, they realized that football fans were not necessarily their clientele and had little demand for their product. The restrictions on using imagery and language related to the World Cup further lessened this demand as the products they offered were seen as inferior.

Regardless of the initial intentions of the local organizing committees, once the contracts were in place with the international federation and their sponsors, the power shifted to the international stakeholders and there is little they could have offered their local businesses. As stated in the introduction, for the South African government, their main priority was to enhance the South African image across the world. Because of this priority, the claims that the international stakeholders put forward were seen as legitimate, or as Mitchell et al. (1997) put it: "the ones who really count” (p. 864). As a consequence, the needs of the local SMEs were seen as less urgent.

In this regard, what the interviewees did not mention might be more valuable than what they did state. While Lim and Kimura (2006) discussed the chain between SMEs and LEs as crucial to creating value for a local economy and to alleviate poverty, none of the respondents brought up this topic. When asked about how their businesses profited from the event, none of them mentioned a new or improved partnership with a LE. One of the last questions in the interview was whether their international relationships had improved because of the event, and not a single owner indicated this was the case. As such, the World Cup did not create any new chains between SMEs and LEs. The CCDI could have played a central role within creating these chains, yet it appears that this was not one of the main priorities of the organization. Instead, they focused on informing the SMEs about what they were and were not allowed to do, and providing strongly regulated opportunities for them at the periphery of the event. Due to the lack of support from the national trade associations (such as the CCDI), the World Cup organizing committee, and the international corporations, there were few opportunities for the SME owners to develop leverage strategies to benefit from the World Cup.

Most owners were still positive about the event afterwards, even though they did not profit from it. They seemed to believe that at a macrolevel the nation did profit from the event, and that the benefits were perhaps received by sectors such as construction and hospitality. Whether the respondents are correct to maintain this perspective is uncertain. While other sectors might have profited more from this event, it might also be that they simply continue to believe some of the economic myths surrounding these mega-sport events that were conveyed by the media and that these other sectors were also unable to profit from the event.

This last finding also highlights the largest limitation of this study. While qualitative studies are not meant to provide a level of representation, the ultimate goal of these studies is meant to offer guidelines and insights for future (quantitative) studies. Since the SMEs in this study were from a single sector, all located in one particular city during this event, the findings of this exploratory study cannot automatically be extrapolated to other sectors or other cities, and need to be interpreted carefully. Since the major restriction for these SME owners was to gain access to the tourists we could expect other industries that have access to the tourists to have done better than the crafts industry. For instance, the hospitality industry might have been able to profit from the tourists as they stayed in their hotels and dined in their restaurants, and retailers in upscale malls might have offered a better (and safer) environment for international tourists to do their shopping.

Future research on the microeconomic effects of these mega-sport events should examine other industries, such as the hospitality, the retail, and the construction industries, and hopefully the insights of this study could offer guidelines for measuring these impacts quantitatively. 


\section{Conclusion}

The responses from the interviewees support existing evidence to the claim that mega-sport events such as the World Cup currently do not have a positive effect on local economies (Crompton, 1995; Hall, 1992, 2004; Hall \& Page, 2008), and that little attempt is made to leverage the event to this end. While these mega-sport events are initially funded by public money, the economic benefits remain with organizations such as the IOC and FIFA and do not extent to local businesses (Cottle, 2010). For such spin-off to occur, the current guarantees set by the international federations for local organizing committees would have to change and allow for larger interaction with local SMEs. For that to happen, the FIFA has to comprehend the notion that the positions of the local stakeholders such as the SMEs does not have to conflict with the interests of the international stakeholders. Most international companies sponsor the World Cup because of the hospitality opportunities the event offers and the brand associations it gives the company across the world (Brown, 2000; Gwinner \& Eaton, 1999). As such, they do not have to exclude the local SMEs from the stadiums' surroundings. Instead, they could initiate local economic stimulus strategies and cooperate with SMEs in order to start a global value chain. Implementing such strategies would allow the international sponsors to position the event as an opportunity for corporate social responsibility and have a positive effect on the reputation of the company (Walker \& Kent, 2009). The formation of these global value chains in which the local SMEs and the international sponsors work together could create the economic spin-off local governments desire. Such initiatives are currently lacking, and would require modification of the current bid conditions.

\section{References}

Archer, B., \& Fletcher, B. (1996). The economic impact of tourism in the Seychelles. Annals of Tourism Research, 23(1), 32-47.

Acs, Z. J. (1992). Small business economics: A global perspective, Challenge, 35, 38-44.

Billings, S. B., \& Holladay, J. S. (2012). Should cities go for the gold? The long-term impacts of hosting the Olympics. Economic Inquiry, 50(3), 754-772.

Bolton, R. N., Kannan, P. K., \& Bramlett, M. D. (2000). Implications of loyalty program membership and service experiences for customer retention and value. Journal of the Academy of Marketing Science, 28(1), 95-108.

Boon, R., \& Bertacchini, S. (2009, November). Trade mark 2010. Published documentary by VPRO Backlight.

Bregoli, I., \& Del Chiappa, G. (2013). Coordinating relationships among destination stakeholders: Evidence from Edinburgh (UK). Tourism Analysis, 18, 145-155.

Brohman, J. (1996). New directions in tourism for third world development. Annals of Tourism Research, 23(1), 48-70.

Brown, G. (2000). Emerging issues in Olympic sponsorship: Implications for host cities. Sport Management Review, 3(1), 71-92.

Burgan, B., \& Mules, T. (1992). Economic impact of sporting events. Annals of Tourism Research, 19, 700-710.

Cape Craft \& Design Institute. (2004). Western Cape Provincial Manufacturing Technology Strategy: Craft sector report. Retrieved February 10, 2011, from http://ccdi.org. za/research-and-publications/research/Provincial\%20 Advanced\%20Manufacturing\%20Technology\%20 Strategy\%20-PAMTS.pdf

Cashman, R. (2005). The bitter-sweet awakening: The legacy of the Sydney 2000 Olympic Games. Sydney: Walla Walla Press.

Chalip, L. (2001). Sport and tourism: Capitalising on the linkage. In D. Kluka \& G. Schilling (Eds.), The business of sport. Oxford, UK: Meyer \& Meyer.

Chalip, L. (2004). Beyond impact: A general model for host community event leverage. In B. W. Ritchie \& D. Adair (Eds.), Sport tourism: Interrelationships, impacts and issues. Clevedon, UK: Channel View Publications.

Chalip, L., \& Leyns, A. (2002). Local business leveraging of a sport event: Managing an event for economic benefit. Journal of Sport Management, 16, 132-158.

Coates, D., \& Humphreys, B. (2002). The economic impact of postseason play in professional sports. Journal of Sports Economics, 3(3), 291-299.

Cottle, E. (2010). A preliminary evaluation of the impact of the 2010 FIFA World CupTM: South Africa. Swiss Labour Assistance SLA.

Crompton, J. L. (1995). Economic impact analysis of sports facilities and events: Eleven sources of misapplication. Journal of Sport Management, 9(1), 14-35.

De Moragas, M., Kennett, C., \& Puig, N. (2003). The legacy of the Olympic Games, 1984-2000. In Proceedings of the International Symposium (pp. 450-456). Lausanne: International Olympic Committee.

Department of Trade \& Industry South Africa. (2004). Annual review of small business in South Africa: 2004, a statistical review. SEDA, Small Enterprise Development Agency.

Enright, M.J., Ffowcs-Williams, I., \& Nolan, A. (2001). Local partnerships, clusters and SME globalisation. In Enhancing SME competitiveness: The OECD Bologna Ministerial Conference (pp. 115-150). Paris: OECD.

FinScope South Africa Small Business Survey. (2010). Finmark trust. Retrieved April 11, 2012, from http://www. finmark.org.za/publication/finscope-south-africa-smallbusiness-survey-2010-report 
Freeman, R. E. (1984). Strategic management: A stakeholder approach. Boston: Pitman.

Goodwin, H. (2000). Pro-poor tourism: Opportunities for sustainable local development. Development and Cooperation, 5, 12-14.

Gwinner, K. P., \& Eaton, J. (1999). Building brand image through event sponsorship: The role of image transfer. Journal of Advertising, 28(4), 47-57.

Hall, C. M. (1992). Hallmark tourist events: Impact, management, and planning. London: Belhaven Press.

Hall, C. M. (2004). Sports tourism and urban regeneration. In B. W. Ritchie \& D. Adair (Eds.), Sport tourism: Interrelationships, impacts and issues. Clevedon, UK: Channel View Publications.

Hall, C. M., \& Page, S. (2008). Progress in tourism management: From the geography of tourism to geographies of tourism-A review. Tourism Management, 30, 3-16.

Harrison, D. (1994). Tourism, capitalism and development in less developed countries. In L. Sklair (Ed.), Capitalism and development (pp. 232-257). London: Routledge.

Haxton, P. (2000). Community involvement and the Olympic Games: A review of related research. In Report on the IOA's special sessions and seminars 1999 (pp. 142-164). Athens: International Olympic Academy.

International Olympic Committee. (2010). Olympic marketing fact file (2010 ed.). Retrieved October 24, 2011, from http://www.olympic.org/documents/fact_file_2010.pdf

Jennings, A. (2010, December 18). The documents that FIFA doesn't want fans to read. Retrieved October 24, 2011, from http://www.transparencyinsport.org/The_documents_ that_FIFA_does_not_want_fans_to_read/the_documents fifa_does_not_want_fans_to_read.html

Jones, C. (2001). Mega-events and host-region impacts: Determining the true worth of the 1999 Rugby World Cup. International Journal of Tourism Research, 3(3), 241-250.

Kasimati, E. (2003). Economic aspects and the Summer Olympics: A review of related research. International Journal of Tourism Research, 5, 433-444.

Kesenne, S. (2005). Do we need an economic impact study or a cost-benefit analysis of a sport event? European Sport Management Quarterly, 5(2), 133-142.

Kimura, F. (2006). International production and distribution networks in East Asia: 18 facts, mechanics and policy implications. In Asian economic policy review. Oxford, UK: Blackwell.

Kirsten, M., \& Rogerson, C. M. (2002). Tourism, business linkages and small enterprise development in South Africa. Development South Africa, 19(1), 29-59.

Lenskyj, H. (2000). Inside the Olympic industry: Power, politics and activism. New York: State University of New York.

Lenskyj , H. (2002). The best Olympics ever? Social impacts of Sydney 2000. New York: State University of New York.

Lim, H., \& Kimura, F. (2009) The internationalisation of SMEs in regional and global value chains. Adbi Working Paper Series, Asian Development Bank Institute.
Matheson, V. (2006a, October). Mega-events: The effect of the world's biggest sporting events on local, regional, and national economies. College of the Holy Cross, Department of Economics, Faculty Research series, Paper No. 06-10. Retrieved February 14, 2013, from http://casgroup.fiu.edu/pages/docs/2744/1277904942 matheson_events.pdf

Matheson, V. (2006b). Is smaller better? A comment on 'comparative economic impact analyses." Economic Development Quarterly, 20(2), 192-195.

Miles, M. B., \& Huberman, A. M. (1994). Qualitative data analysis: An expanded sourcebook (2nd ed.). Thousand Oaks, CA: Sage.

Mitchell, R. K., Agle, B. R., \& Wood, D. T. (1997). Toward a theory of stakeholder identification and salience: Defining the principles of who and what really counts. The Academy of Management Review, 22(4), 853-886.

O'Leary, Z. (2005). Researching real-world problems: A guide to methods of inquiry. London: Sage Publications.

Organisation for Economic Co-operation and Development. (2007). Enhancing the role of SMEs in global value chains. Paris: Author.

Parent, M. M. (2008). Evolution and issue patterns for majorsport-event organizing committees and their stakeholders. Journal of Sport Management, 22, 135-164.

Preuss, H. (2003). The economics of the Olympic Games: Winners and losers. In: B. Houlihan (Ed.), Sport and society (pp. 252-272). London: Sage.

Preuss, H. (2004). The economics of staging the Olympics: A comparison of the Games 1972-2008. Cheltenham, UK: Edward Elgar Publishing.

Rambler, S. (2010, June 16, 2010). FIFA World Cup 2010: Money makes the world go round. The Bleacher Report. Retrieved February 14, 2013, from http://bleacherreport. com/articles/406843-money-makes-the-world-cup-goround

Ritchie, J., \& Aitken, C. (1984). Olympulse I: The research program and initial results. Journal of Travel Research, 22(1), 17-25.

Rose, A. K., \& Spiegel, M. M. (2009). The Olympic effect. Federal Reserve Bank of San Francisco Working Paper Series.

Sandelowski, M. (1995). Sample size in qualitative research. Research in Nursing and Health, 18, 179-183.

Schumpeter, J. A. (1934). The theory of economic development: An inquiry into profits, capital, credit, interest, and the business cycle. Piscataway, NJ: Transaction Publishers.

Shaw, C. A. (2008). Five ring circus: Myths and realities of the Olympic Games. Gabriola Island, Canada: New Society Publishers.

Slywotsky, A. J., \& Shapiro, B. P. (1993). Leveraging to beat the odds: The new marketing mind-set. Harvard Business Review, 71(5), 97-107.

South African Tourism. (2010). Impact of 2010 FIFA World Cup. Retrieved April 10, 2012, from http://www.southafrica.net/uploads/legacy/1/335208/World_Cup_Impact_ Study_v8_report_03122010.pdf

U.S. Small Business Administration (2012). Small business size standards. Retrieved April 11, 2012, from http:// 
www.sba.gov/category/navigation-structure/contracting/ contracting-officials/size-standards

Ubabuko, K., Ally Kavuwo, H., Kwaasi Adjei, E., \& Shahihuzzaman, M. (2010). Analysis of the SME sector in Tanzania and Ghana. Gotland University, School of the Humanities and Social science. Retrieved March 31, 2014, from: http://www.diva-portal.org/smash/record.jsf? pid=diva2:359333

Vigor, A., Mean, M., \& Tims, C. (Eds.) (2004). After the gold rush. A sustainable Olympics for London. London: IPPR.
Walker, M., Kaplanidou, K., Gibson, H., Thapa, B., Geldenhuys, S., \& Coetzee, W. (2013). "Win in Africa, with Africa”: Social responsibility, event image, and destination benefits. The case of the 2010 FIFA World Cup in South Africa. Tourism Management, 34, 80-90.

Walker, M., \& Kent, A. (2009). Do fans care? Assessing the influence of corporate social responsibility on consumer attitudes in the sport industry. Journal of Sport Management, 23, 743-769. 